\title{
Sodium Transport from Blood to Brain: Inhibition by Furosemide and Amiloride
}

\author{
A. Lorris Betz \\ Departments of Pediatrics and Neurology, University of Michigan, Ann Arbor, Michigan, U.S.A.
}

\begin{abstract}
Brain sodium uptake in vivo was studied using a modified intracarotid bolus injection technique in which the uptake of ${ }^{22} \mathrm{Na}^{+}$was compared with that of the relatively impermeable molecule, $\left[{ }^{3} \mathrm{H}\right] \mathrm{L}$-glucose. At a $\mathrm{Na}^{+}$ concentration of $1.4 \mathrm{mM}, \mathrm{Na}^{+}$uptake was $1.74 \pm 0.07$ times greater than $\mathrm{L}$-glucose uptake. This decreased to $1.34 \pm 0.04$ at $140 \mathrm{mM} \mathrm{Na}{ }^{+}$, indicating saturable $\mathrm{Na}^{+}$ uptake. Relative $\mathrm{Na}^{+}$extraction was not affected by $\mathrm{pH}$ but was inhibited by amiloride $\left(K_{\mathrm{i}}=3 \times 10^{-7} M\right)$ and by $1 \mathrm{~m} M$ furosemide. The effects of these two inhibitors were additive. Brain uptake of ${ }^{86} \mathrm{Rb}^{+}$, a $\mathrm{K}^{+}$analogue, was measured to study interaction of $\mathrm{K}^{+}$with $\mathrm{Na}^{+}$transport
\end{abstract}

systems. Relative ${ }^{86} \mathrm{Rb}^{+}$extraction was also inhibited by amiloride; however, it was not inhibited by furosemide. The results suggest the presence of two distinct transport systems that allow $\mathrm{Na}^{+}$to cross the luminal membrane of the brain capillary endothelial cell. These transport systems could play an important role in the movement of $\mathrm{Na}^{+}$from blood to brain. Key Words: Blood-brain barrier-Cerebrospinal fluid-Brain sodium uptake-Brain potassium uptake-Amiloride-Furosemide. Betz A. L. Sodium transport from blood to brain: Inhibition by furosemide and amiloride. $J$. Neurochem. 41, 1158-1164 (1983).
The tight junctions in brain capillaries form a permeability barrier that prevents blood-to-brain transfer of many compounds including ions (Bouldin and Krigman, 1975; Dorovini-Zis et al., 1980). Polar solutes that enter brain from blood must do so via specific carriers in the capillary endothelial cell membranes or by moving from blood to CSF across the choroid plexus. Although the capacity of $\mathrm{Na}^{+}$ to cross the blood-brain and blood-CSF barriers is limited, its brain uptake is greater than that of other polar molecules such as mannitol (Smith et al., $1981 a$ ). Therefore it seems likely that specific transport systems for $\mathrm{Na}^{+}$are present in the brain capillary, the choroid plexus, or both.

There have been many studies of $\mathrm{Na}^{+}$transport at the choroid plexus, both in vivo (Smith et al., $1981 b$ ) and in vitro (Pollay et al., 1972; Wright, 1972), and a model for transepithelial transport of $\mathrm{Na}^{+}$in this tissue has been proposed (Wright, 1972). By comparison, there have been relatively few studies of $\mathrm{Na}^{+}$transport at the blood-brain barrier (BBB). Although the permeability of the $\mathrm{BBB}$ to $\mathrm{Na}^{+}$has been measured in vivo (see Bradbury, 1979 for re- view), the only studies on possible mechanisms of BBB $\mathrm{Na}^{+}$transport were performed using isolated brain microvessels (Goldstein, 1979; Eisenberg and Suddith, 1979). These studies demonstrated the presence in brain capillaries of $\mathrm{Na}^{+}, \mathrm{K}^{+}$-ATPase which was subsequently localized on the antiluminal but not the luminal membrane of the brain capillary endothelial cell (Betz et al., 1980). It is likely that this active $\mathrm{Na}^{+}$pump would be involved in transendothelial $\mathrm{Na}^{+}$transport by pumping $\mathrm{Na}^{+}$ out of the endothelial cell cytoplasm into the brain interstitial space. The mechanisms by which $\mathrm{Na}^{+}$ moves from the blood across the luminal membrane and into the cytoplasm of the endothelial cell, however, remain unknown.

The purpose of this investigation was to identify transport systems that are involved in the transfer of $\mathrm{Na}^{+}$from blood to brain. For selective study of transport across the luminal membrane of the brain capillary, I used a modification of the intracarotid bolus injection technique (Oldendorf 1971), which measures relative tracer extraction from the blood during a single circulatory pass. The results suggest
Received January 20, 1983; accepted May 3, 1983.

Address correspondence and reprint requests to A. Lorris Betz, M.D., Ph.D., Department of Pediatrics, R6060 Kresge Research II, Ann Arbor, MI 48109, U.S.A.
Abbreviations used: BBB, Blood-brain barrier; BUI, Brain uptake index; RE, Relative extraction. 
that there are at least two $\mathrm{Na}^{+}$transport systems on the luminal membrane of the brain capillary. One can be inhibited by the diuretic amiloride, and the other by furosemide. A preliminary report describing some of this work was presented previously (Betz, 1982).

\section{MATERIALS AND METHODS}

The technique used to measure $\mathrm{Na}^{+}$and $\mathrm{Rb}^{+}$uptake from blood to brain is a modification of the intracarotid bolus injection technique developed by Oldendorf (1971). In the original studies with this procedure, the injection solution contained two radiolabeled solutes, a freely permeable reference compound such as ${ }^{3} \mathrm{H}_{2} \mathrm{O}$, and a ${ }^{14} \mathrm{C}$ labeled test compound whose permeability was to be determined. A subsequent modification of this procedure permitting more accurate uptake determinations of compounds with low permeability used $\left[{ }^{3} \mathrm{H}\right]$ tryptamine, with 10-fold lower permeability than ${ }^{3} \mathrm{H}_{2} \mathrm{O}$, as a reference compound (Oldendorf and Braun, 1976). In the course of the present study, I found it advantageous to use a reference compound with even lower permeability, as uptake of the test solute, ${ }^{22} \mathrm{Na}^{+}$, was very low. For most of these experiments, $\left[{ }^{3} \mathrm{H}\right] \mathrm{L}-\mathrm{glucose}$ was used as a reference compound. The BBB is nearly impermeable to this stereoisomer of D-glucose (Oldendorf, 1976).

Male Sprague-Dawley rats weighing $300-350 \mathrm{~g}$ were anesthetized with pentobarbital $(60 \mathrm{mg} / \mathrm{kg}$ i.p.). The right common carotid artery was exposed and cannulated with a 27-gauge needle. A solution, $0.2-\mathrm{ml}$ samples of which contained $3 \mu \mathrm{Ci}$ of ${ }^{22} \mathrm{Na}^{+}$or ${ }^{86} \mathrm{Rb}^{+}$and $15 \mu \mathrm{Ci}$ of $\left[{ }^{3} \mathrm{H}\right] \mathrm{L}-$ glucose, was rapidly injected into the carotid circulation. Five seconds later the animal was decapitated, the brain removed, and the right cerebral hemisphere quickly cleared of meninges, surface blood vessels, and choroid plexus. The brain sample was dissolved in Protosol and prepared for liquid scintillation counting in a nonaqueous counting solution. A sample of the injection solution was also prepared for scintillation counting by addition to a vial containing Protosol and a portion of brain from an uninjected animal. The content of ${ }^{22} \mathrm{Na}^{+}$(or ${ }^{86} \mathrm{Rb}^{+}$) and ${ }^{3} \mathrm{H}$ in each sample was determined using a Beckman LS7500 scintillation counter that had been previously calibrated for dual-label analysis of these isotopes.

The ratio of ${ }^{22} \mathrm{Na}^{+}$(or ${ }^{86} \mathrm{Rb}^{+}$) to ${ }^{3} \mathrm{H}$ in the brain sample was divided by the same ratio in the injected mixture. This resulted in a ratio termed the relative extraction (RE) of ${ }^{22} \mathrm{Na}^{+}$compared with the ${ }^{3} \mathrm{H}$ reference compound.

$$
R E=\frac{\left({ }^{22} \mathrm{Na} / 3 \mathrm{H}\right)_{\text {br }}}{\left({ }^{22} \mathrm{Na} /{ }^{3} \mathrm{H}\right)_{\text {inj }}}
$$

The RE value is analogous to the brain uptake index (BUI) of Oldendorf (1971), except that it cannot be readily converted to a quantitative measure of extraction because a precise value for extraction of the reference compound is not known. Nevertheless, the extraction of ${ }^{22} \mathrm{Na}^{+}$relative to L-glucose can be determined and the effect of potential transport inhibitors investigated.

The composition of the injection solution was varied to test the effects of ion concentrations or drugs on $\mathrm{Na}^{+}$ uptake. For most experiments, the solution contained 1.4 $\mathrm{m} M \mathrm{NaCl}, 10 \mathrm{~m} M$ Tris- $\mathrm{HCl}$ (pH 7.4), and $5 \mathrm{~m} M$ D-glucose; it was made isotonic with sucrose. When the $\mathrm{NaCl}$ concentration was increased, the sucrose content was decreased proportionately. Isotonic replacement of $\mathrm{NaCl}$ with choline chloride rather than sucrose had no effect on ${ }^{22} \mathrm{Na}^{+}$uptake under control conditions. There was also no difference in control experiments if the animal was decapitated $15 \mathrm{~s}$ rather than $5 \mathrm{~s}$ after isotope injection. To eliminate volatile contaminants, stock solutions of ${ }^{3} \mathrm{H}$ sugars were evaporated to dryness prior to use.

The significance of the difference in RE between different groups was determined by Student's $t$-test. When multiple comparisons were made, the Bonferroni method was used to correct the $t$-statistic (Wallenstein et al., 1980).

\section{Materials}

$\left[{ }^{3} \mathrm{H}\right]_{\mathrm{L}}$-glucose $(10.7 \mathrm{Ci} / \mathrm{mmol}),\left[{ }^{3} \mathrm{H}\right]$ sucrose $(10.8 \mathrm{Ci} /$ $\mathrm{mmol}),{ }^{3} \mathrm{H}_{2} \mathrm{O}(1.0 \mathrm{Ci} / \mathrm{g}),{ }^{22} \mathrm{NaCl}$ (carrier-free), ${ }^{86} \mathrm{RbCl}(1.1$ $\mathrm{Ci} / \mathrm{g}$ ), and Protosol were obtained from New England $\mathrm{Nu}-$ clear (Boston, MA). Amiloride was a gift from Merck, Sharp and Dohme Research Laboratories (Rahway, NJ), and furosemide (Lasix) was provided by Hoechst-Roussel Pharmaceuticals (Somerville, NJ). All other chemicals were purchased from Sigma Chemical (St. Louis, MO).

\section{RESULTS}

Preliminary experiments were designed to identify a useful reference compound for ${ }^{22} \mathrm{Na}^{+}$uptake measurements. Table 1 shows results obtained with a highly permeable reference $\left({ }^{3} \mathrm{H}_{2} \mathrm{O}\right)$ and with several compounds having low BBB permeability. Uptake of ${ }^{22} \mathrm{Na}^{+}$compared with that of ${ }^{3} \mathrm{H}_{2} \mathrm{O}$ is very low and near the limit of detection for this reference compound (Oldendorf and Braun, 1976) (an RE of 0.035 is equal to a BUI of $3.5 \%$ ). The ${ }^{3} \mathrm{H}_{2} \mathrm{O}$ reference method also is not sufficiently sensitive to detect the concentration-dependent changes in ${ }^{22} \mathrm{Na}^{+}$ extraction. In contrast, the extraction of ${ }^{22} \mathrm{Na}^{+}$is greater (i.e., RE $>1.0$ ) than that of a low-permeability compound such as L-glucose. Further, when the concentration of $\mathrm{Na}^{+}$is increased from 1.4 to $140 \mathrm{mM}$ a significant decrease in the RE value can be measured.

The concentration dependence of brain $\mathrm{Na}^{+}$uptake was investigated in greater detail by measuring ${ }^{22} \mathrm{Na}^{+}$extraction relative to $\left[{ }^{3} \mathrm{H}\right] \mathrm{L}$-glucose at $\mathrm{Na}^{+}$ concentrations from 0.07 to $140 \mathrm{mM}$ (Fig. 1). The

TABLE 1. Extraction of ${ }^{22} \mathrm{Na}$ relative to various references

\begin{tabular}{lrc}
\hline & \multicolumn{3}{c}{ Relative extraction } \\
\cline { 2 - 3 } Reference compound & $\mathrm{Na}^{+}=1.4 \mathrm{mM}$ & $\mathrm{Na}^{+}=140 \mathrm{mM}$ \\
\hline${ }^{3} \mathrm{H}_{2} \mathrm{O}$ & $0.045 \pm 0.010(6)$ & $0.035 \pm 0.002(5)$ \\
{$\left[{ }^{3} \mathrm{H}\right]$ L-glucose } & $1.74 \pm 0.07(6)$ & $1.34 \pm 0.04(5)^{a}$ \\
{$\left[{ }^{3} \mathrm{H}\right]$ Sucrose } & $1.36 \pm 0.05(3)$ & $1.17 \pm 0.01(3)^{a}$ \\
{$\left[{ }^{3} \mathrm{H}\right]$ Mannitol } & $1.33 \pm 0.10(3)$ & \\
\hline
\end{tabular}

Relative extraction of ${ }^{22} \mathrm{Na}(3 \mu \mathrm{Ci} / 0.2 \mathrm{ml})$ was measured using either ${ }^{3} \mathrm{H}_{2} \mathrm{O}(0.5 \mu \mathrm{Ci} / 0.2 \mathrm{ml})$ or ${ }^{3} \mathrm{H}$-labeled sugars $(15 \mu \mathrm{Ci} / 0.2 \mathrm{ml})$ at low and high $\mathrm{NaCl}$ concentrations. Sucrose was substituted for $\mathrm{NaCl}$ for the low concentration. Values shown are averages \pm SEM with the number of de terminations in parentheses.

${ }^{a} \mathrm{p}<0.01$ (compared with $\mathrm{Na}^{+}=1.4 \mathrm{mM}$ with same reference). 


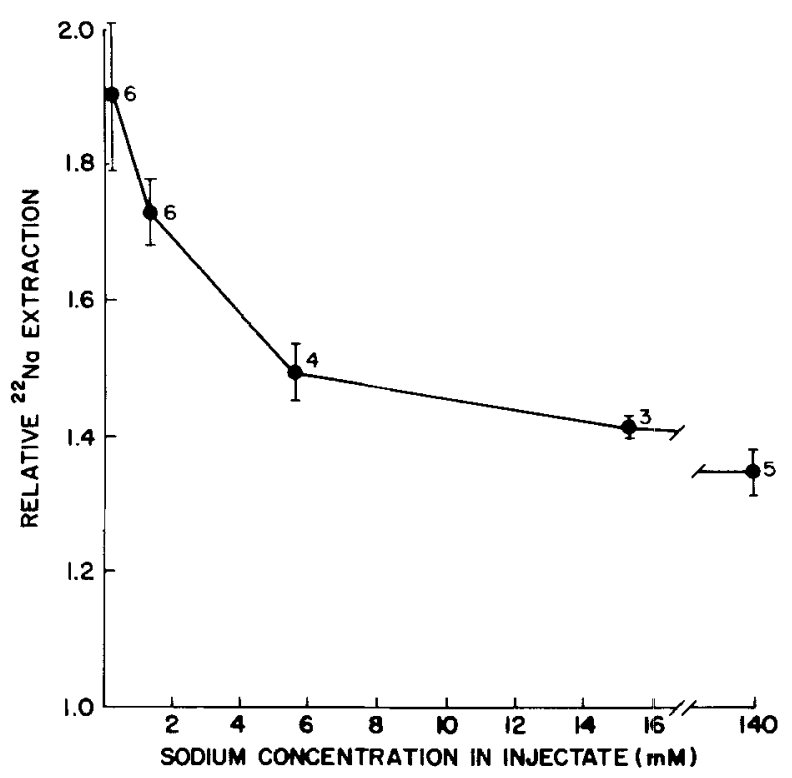

FIG. 1. Effect of sodium concentration on brain ${ }^{22} \mathrm{Na}^{+}$uptake. Brain extraction of ${ }^{22} \mathrm{Na}^{+}$was measured relative to $\left[{ }^{3} \mathrm{H}\right] \mathrm{L}-$ glucose with various concentrations of $\mathrm{NaCl}$ in the injected solution. The injectate also contained $5 \mathrm{mM}$ glucose, $10 \mathrm{mM}$ Tris- $\mathrm{HCl}(\mathrm{pH} \mathrm{7.4)}$ and was made isotonic with sucrose. Points are averages \pm SEM for the number of observations shown.

progressive decline in ${ }^{22} \mathrm{Na}^{+}$extraction as the unlabeled $\mathrm{Na}^{+}$concentration increased indicates that a saturable process is involved in brain $\mathrm{Na}^{+}$uptake. Assuming that only one transport system is involved, the data in Fig. 1 can be used to estimate a $K_{\mathrm{m}}$ for this process (Pardridge and Oldendorf, 1975 ). The value obtained, $K_{\mathrm{m}}=2.5 \mathrm{~m} M$, indicates that brain $\mathrm{Na}^{+}$uptake is nearly saturated at physiologic serum $\mathrm{Na}^{+}$concentrations. A mechanistic interpretation of this kinetic constant is difficult, however, as subsequent experiments indicate that $\mathrm{Na}^{+}$uptake occurs by more than one transport system.

Two inhibitors that have been used extensively to characterize $\mathrm{Na}^{+}$transport in many types of epithelia are the diuretics amiloride and furosemide. As shown in Fig. 2, each of these compounds caused a significant $(\mathrm{p}<0.05)$ reduction in the $\mathrm{RE}$ for $\mathrm{Na}^{+}$ at a low $\mathrm{Na}^{+}$concentration. Although neither compound alone inhibited brain $\mathrm{Na}^{+}$uptake to the same extent as did $140 \mathrm{mM} \mathrm{Na}{ }^{+}$, this level of inhibition was achieved when the two diuretics were added together. At a Na${ }^{+}$concentration of $140 \mathrm{mM}$, neither drug caused a significant further decrease in $\mathrm{Na}^{+}$extraction. These results suggest the presence of two separate transport systems for $\mathrm{Na}^{+}$at the BBB.

In epithelial cells, amiloride inhibits two distinct types of $\mathrm{Na}^{+}$transport systems (Benos, 1982). One is a conductive $\mathrm{Na}^{+}$pathway found in many highresistance epithelia. The $K_{\mathrm{i}}$ of amiloride for this $\mathrm{Na}^{+}$ pore system is typically between $10^{-7}$ and $10^{-6} M$.

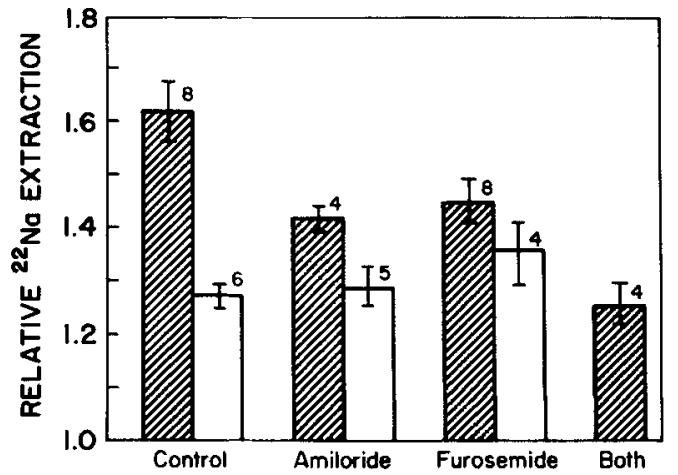

FIG. 2. Effects of diuretics on brain ${ }^{22} \mathrm{Na}^{+}$uptake. Brain extraction of ${ }^{22} \mathrm{Na}^{+}$was measured relative to $\left[{ }^{3} \mathrm{H}\right] \mathrm{L}-\mathrm{glucose}$ in the absence (control) or presence of amiloride $(1 \mathrm{mM})$ or furosemide $(1 \mathrm{mM})$. When the two diuretics were both present, the amiloride concentration was reduced to $0.1 \mathrm{mM}$ to avoid precipitation of furosemide $(1 \mathrm{mM})$. The injectate sodium concentration was either $1.4 \mathrm{mM}$ (striped) or $140 \mathrm{mM}$ (clear). Values are averages \pm SEM for the number of observations shown.

Amiloride can also inhibit an electroneutral $\mathrm{Na}^{+} / \mathrm{H}^{+}$ exchange system, however, in this case with a $K_{\mathrm{i}}$ of $10^{-5}-10^{-4} M$. Furosemide does not inhibit either of these $\mathrm{Na}^{+}$transport systems, but rather it inhibits coupled $\mathrm{NaCl}$ transport systems (Warnock and Eveloff, 1982). A dose-response curve for the inhibition of brain $\mathrm{Na}^{+}$uptake by amiloride is shown in Fig. 3. An approximate value for the $K_{\mathrm{i}}$ is $3 \times$ $10^{-7} M$.

The effect of replacing chloride in the injection solution with other anions is shown in Table 2. There is a significant reduction in $\mathrm{Na}^{+}$extraction when

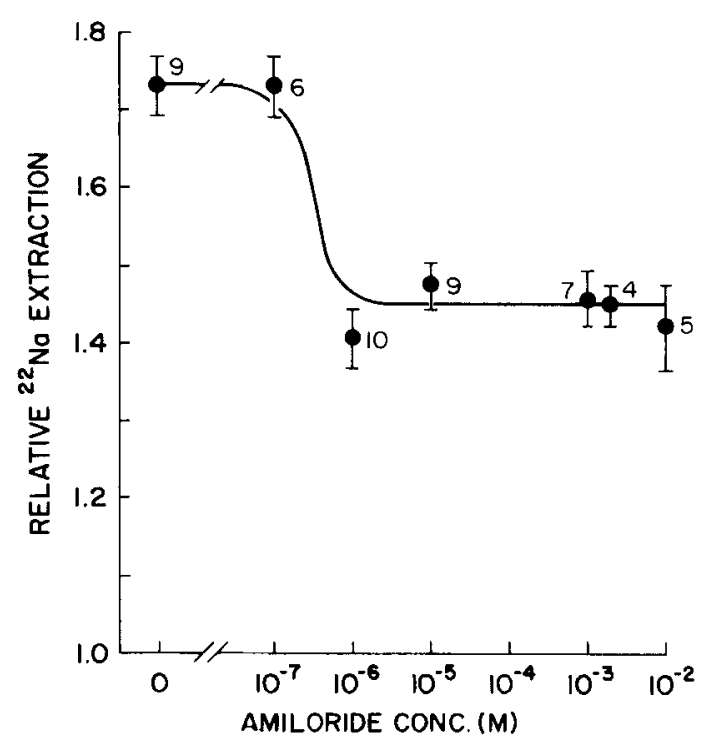

FIG. 3. Effect of amiloride concentration on brain ${ }^{22} \mathrm{Na}^{+}$uptake. Brain extraction of ${ }^{22} \mathrm{Na}^{+}$relative to $\left[{ }^{3} \mathrm{H}\right] \mathrm{L}-\mathrm{glucose}$ was measured with the injectate containing $1.4 \mathrm{mM} \mathrm{Na}^{+}$and various concentrations of amiloride. Points are averages \pm SEM for the number of observations shown. 
TABLE 2. Effects of various anions and cations on brain $\mathrm{Na}^{+}$extraction

\begin{tabular}{ll}
\hline \multicolumn{1}{c}{ Injected solution } & Relative extraction \\
\hline $1.4 \mathrm{~m} M \mathrm{NaCl}^{\prime}$ & $1.73 \pm 0.05(6)$ \\
$1.4 \mathrm{~m} M \mathrm{NaHCO}_{3}$ & $1.75 \pm 0.10(3)$ \\
$1.4 \mathrm{~m} M \mathrm{NaI}$ & $1.45 \pm 0.06(4)^{a}$ \\
$1.4 \mathrm{~m} M \mathrm{NaSCN}$ & $1.59 \pm 0.08(3)$ \\
$1.4 \mathrm{~m} M \mathrm{NaAcetate}$ & $1.60 \pm 0.11(3)$ \\
$1.4 \mathrm{~m} M \mathrm{NaCl}+4 \mathrm{~m} M \mathrm{LiCl}$ & $1.43 \pm 0.04(6)^{a}$ \\
$1.4 \mathrm{~m} M \mathrm{NaCl}+4 \mathrm{~m} M \mathrm{KCl}$ & $1.41 \pm 0.02(8)^{a}$ \\
$1.4 \mathrm{~m} M \mathrm{NaCl}+140 \mathrm{~m} M$ choline chloride & $1.64 \pm 0.06(5)$ \\
\hline
\end{tabular}

${ }^{22} \mathrm{Na}^{+}$extraction was measured relative to $\left[{ }^{3} \mathrm{H}\right] \mathrm{L}-$ glucose. The injected solution contained $1.4 \mathrm{mM} \mathrm{Na}{ }^{+}$salt, isotonic sucrose, $5 \mathrm{mM}$ glucose, and $10 \mathrm{~m} M$ HEPES adjusted to $\mathrm{pH} 7.4$ with Tris base. Values shown are averages \pm SEM with the number of determinations in parentheses.

${ }^{a} \mathrm{p}<0.01$ (compared with $1.4 \mathrm{mM} \mathrm{NaCl}$ )

$\mathrm{Cl}^{-}$is replaced with $\mathrm{I}^{-}$but not when it is replaced with $\mathrm{HCO}_{3}{ }^{-}$. This is consistent with $\mathrm{Na}^{+}-\mathrm{Cl}^{-}$cotransport system in which $\mathrm{Cl}^{-}$can be replaced by $\mathrm{HCO}_{3}{ }^{-}$. Also shown in Table 2 are a significant inhibition of RE for $\mathrm{Na}^{+}$when $4 \mathrm{mM} \mathrm{Li}{ }^{+}$or $4 \mathrm{mM}$ $\mathrm{K}^{+}$is added to the injectate but not if $140 \mathrm{~m} M$ choline chloride is used. The effect of varying the $\mathrm{pH}$ of the injection solution from 6.2 to 8.4 is shown in Fig. 4. There is little effect on either the RE at 1.4 $\mathrm{mM} \mathrm{Na}{ }^{+}$or on the inhibition by amiloride. However, there is a significant reduction in the effectiveness of auto-inhibition by $140 \mathrm{mM} \mathrm{Na}{ }^{+}$when the $\mathrm{pH}$ is increased from 6.2 to 8.4. This suggests

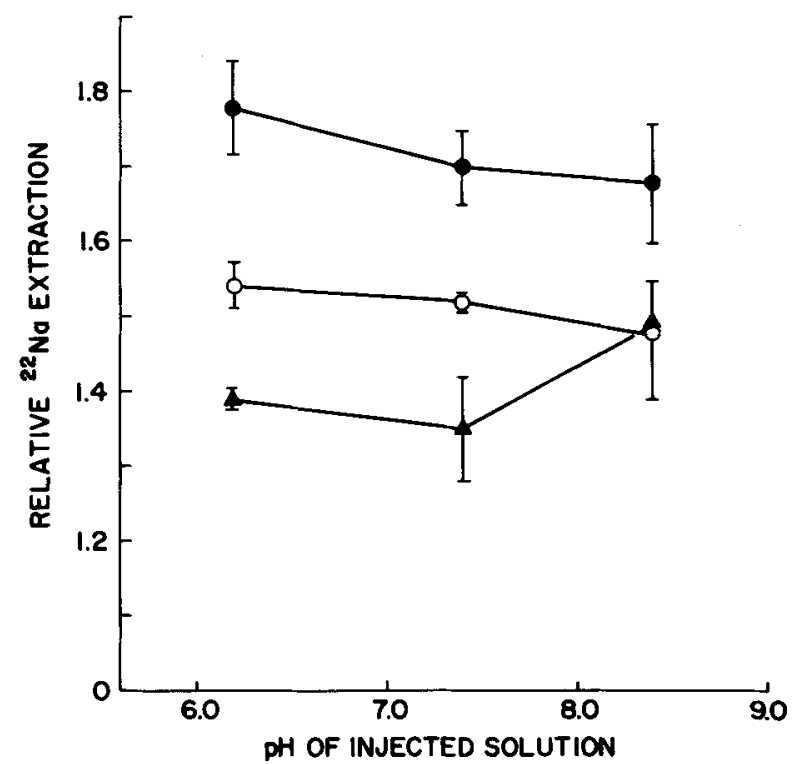

FIG. 4. Effect of $\mathrm{pH}$ on brain ${ }^{22} \mathrm{Na}^{+}$uptake. Brain extraction of ${ }^{22} \mathrm{Na}^{+}$relative to $\left[{ }^{3} \mathrm{H}\right] \mathrm{L}-\mathrm{glucose}$ was measured using injection solutions buffered with $10 \mathrm{mM}$ 2-[N-morpholino]ethanesulfonic acid (Mes, $\mathrm{pH}$ 6.2), $10 \mathrm{mM}$ HEPES (pH 7.4), or $10 \mathrm{mM} \mathrm{N}, \mathrm{N}$-bis[2-hydroxyethyl]-glycine (Bicine, $\mathrm{pH}$ 8.4). The $\mathrm{pH}$ of each solution was adjusted using Tris base. The sodium concentration was $1.4 \mathrm{mM}(\mathbf{0}), 1.4 \mathrm{mM}+$ $1 \mathrm{mM}$ amiloride $(O)$, or $140 \mathrm{mM}(\Delta)$. Points are averages \pm SEM for three to four observations. a stimulation in unidirectional movement of $\mathrm{Na}^{+}$ from blood to brain at alkaline $\mathrm{pH}$.

For further characterization of potential interactions between $\mathrm{Na}^{+}$and $\mathrm{K}^{+}$transport, 1 measured the brain extraction of ${ }^{86} \mathrm{Rb}^{+}$under various conditions. This radioactive compound is commonly used as an alternate substrate for $\mathrm{K}^{+}$transport systems such as the $\mathrm{Na}^{+}, \mathrm{K}^{+}$-ATPase (Goldstein, 1979) and the $\mathrm{Na}^{+}-\mathrm{K}^{+}-\mathrm{Cl}^{-}$cotransport systems (McRoberts et al., 1982). As shown in Fig. $5,{ }^{86} \mathrm{Rb}^{+}$is extracted by brain to a greater extent than $\left[{ }^{3} \mathrm{H}\right] \mathrm{L}$-glucose. The $\mathrm{RE}$ for ${ }^{86} \mathrm{Rb}^{+}$is greater at a low $\mathrm{Na}^{+}$concentration than it is at a high $\mathrm{Na}^{+}$concentration, consistent with competition between $\mathrm{Na}^{+}$and $\mathrm{Rb}^{+}$. This is confirmed by the amiloride sensitivity of ${ }^{86} \mathrm{Rb}^{+}$uptake. However, ${ }^{86} \mathrm{Rb}^{+}$uptake is not affected by either furosemide or ouabain (Fig. 5). The latter observations suggest that neither $\mathrm{Na}^{+}, \mathrm{K}^{+}$-ATPase nor $\mathrm{Na}^{+}-\mathrm{K}^{+}-\mathrm{Cl}^{-}$transporters are present on the luminal membrane of the brain capillary.

Potassium itself also inhibits ${ }^{22} \mathrm{Na}^{+}$and ${ }^{86} \mathrm{Rb}^{+} \mathrm{ex}-$ traction (Table 3). The presence of $4 \mathrm{mM} \mathrm{KCl}$ inhibits ${ }^{86} \mathrm{Rb}^{+}$to the same extent as does $1 \mathrm{~m} M$ amiloride, and the effect of $\mathrm{K}^{+}$is not additive with the diuretic. In contrast, the inhibitory effect of $\mathrm{K}^{+}$on ${ }^{22} \mathrm{Na}^{+}$extraction is additive with both amiloride and furosemide.

\section{DISCUSSION}

There is ample evidence to support the notion that production of CSF occurs by an active secretory process in which water movement is coupled to transport of $\mathrm{Na}^{+}$and $\mathrm{Cl}^{-}$(Wright, 1972; Bradbury, 1979; Smith et al., 1981b). There is general agreement that the choroid plexus is the primary site of this active fluid secretion. However, it appears that under some experimental conditions, as much as one-third of CSF is produced by some structure other than the choroid plexus (Pollay and Curl, 1967;

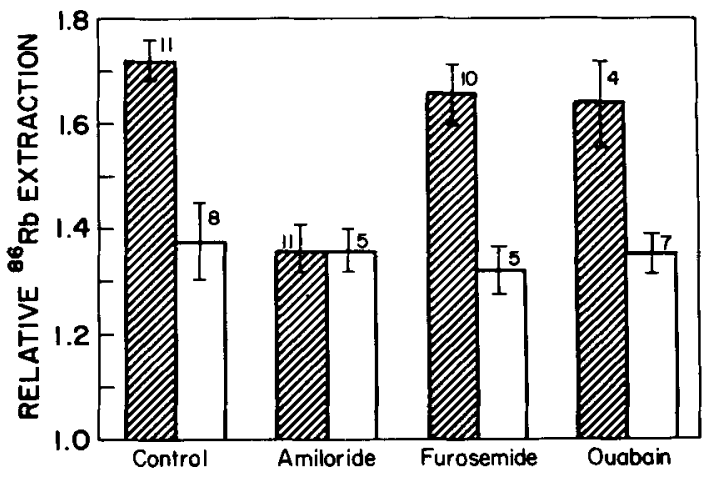

FIG. 5. Effect of several drugs on brain ${ }^{86} \mathrm{Rb}^{+}$uptake. Brain extraction of ${ }^{86} \mathrm{Rb}^{+}$relative to $\left[{ }^{3} \mathrm{H}\right] \mathrm{L}$-glucose was measured in the absence (control) or presence of potential inhibitors (each at $1 \mathrm{mM}$ ). The concentration of $\mathrm{Rb}^{+}$was $0.3 \mathrm{mM}$ and $\mathrm{Na}^{+}$was $1.4 \mathrm{mM}$ (striped) or $140 \mathrm{mM}$ (clear). Values are averages \pm SEM for the number of observations shown. 
TABLE 3. Effects of potassium on ${ }^{22} \mathrm{Na}^{+}$and ${ }^{86} \mathrm{Rb}^{+}$extraction

\begin{tabular}{|c|c|c|c|}
\hline \multirow[b]{2}{*}{ Inhibitor } & \multirow{2}{*}{$\begin{array}{l}\text { Potassium } \\
\text { concentration } \\
(\mathrm{m} M)\end{array}$} & \multicolumn{2}{|c|}{ Relative extraction } \\
\hline & & ${ }^{22} \mathrm{Na}^{+}$ & ${ }^{86} \mathrm{Rb}^{+}$ \\
\hline Control & 0 & $1.62 \pm 0.06(8)$ & $1.72 \pm 0.04$ \\
\hline Control & 4 & $1.41 \pm 0.02(8)^{b}$ & $1.40 \pm 0.06(11)^{b}$ \\
\hline Amiloride & 0 & $1.42 \pm 0.05$ & $1.36 \pm 0.05(11)$ \\
\hline Amiloride & 4 & $1.28 \pm 0.01(10)^{b}$ & $1.42 \pm 0.04(9)$ \\
\hline Furosemide & 0 & $1.45 \pm 0.04(4)$ & $1.66 \pm 0.07(10)$ \\
\hline Furosemide & 4 & $1.32 \pm 0.04(10)^{a}$ & $1.41 \pm 0.08(4)^{a}$ \\
\hline
\end{tabular}

Brain extraction of either ${ }^{22} \mathrm{Na}^{+}$or ${ }^{86} \mathrm{Rb}^{+}$was measured relative to $\left[{ }^{3} \mathrm{H}\right] \mathrm{L}$-glucose. The injection solution contained $1.4 \mathrm{mM} \mathrm{NaCl}, 10 \mathrm{~m} M$ Tris- $\mathrm{HCl}(\mathrm{pH}=7.4)$, and 5 $\mathrm{m} M$ glucose and was made isotonic with sucrose. When present, the concentrations of other constituents were $\mathrm{Rb}^{+}, 0.3 \mathrm{~m} M$; amiloride, $1 \mathrm{~m} M$; and furosemide, $1 \mathrm{~m} M$. Values shown are averages \pm SEM with the number of determinations in parentheses.

${ }^{a} \mathrm{p}<0.05$ (compared with same solution without $\mathrm{K}^{+}$).

$b \mathrm{p}<0.005$ (compared with same solution without $\mathrm{K}^{+}$).

Milhorat et al., 1971; Rosenberg et al., 1980). The most likely location for production of this additional CSF is the BBB formed by brain capillary endothelial cells. Although the permeability of the BBB to $\mathrm{Na}^{+}$is low, the large surface area of brain capillaries compared with choroid plexus provides the potential for a significant total flux (Bradbury, 1979). Therefore, the mechanisms responsible for $\mathrm{Na}^{+}$ transport across brain capillaries are of interest.

The rate of $\mathrm{Na}^{+}$movement from blood to brain has been measured and is relatively uniform among several different species (see Bradbury, 1979 for summary). In a pharmacologic study of possible mechanisms for $\mathrm{BBB} \mathrm{Na}{ }^{+}$transport, Davson and Segal (1970) were unable to inhibit the rate of ${ }^{22} \mathrm{Na}^{+}$ turnover in brain using acetazolamide, ouabain, amphotericin B, or spirolactone. Amiloride appeared to lower the rate of ${ }^{22} \mathrm{Na}^{+}$movement from blood to brain; however, this could not be confirmed by actual measurement of brain ${ }^{22} \mathrm{Na}^{+}$content. Thus previous studies of $\mathrm{Na}^{+}$transport at the BBB were unable to define the mechanisms involved in brain $\mathrm{Na}^{+}$uptake.

In the present investigation, I used a modification of the intracarotid bolus injection technique to study brain uptake of ${ }^{22} \mathrm{Na}^{+}$or ${ }^{86} \mathrm{Rb}^{+}$relative to $\left[{ }^{3} \mathrm{H}\right] \mathrm{L}^{-}$ glucose. Since the actual permeability of $\mathrm{L}$-glucose was not determined and because the data were not corrected for residual intravascular radioactivity, it was not possible to quantitate unidirectional ion movements. Nevertheless, relative changes in uptake of ${ }^{22} \mathrm{Na}^{+}$and ${ }^{86} \mathrm{Rb}^{+}$could be observed and the response to transport inhibitors was studied. The approach assumes that the experimental manipulations did not change L-glucose uptake. This seems likely because L-glucose is not ionized and enters brain by simple diffusion (Gjedde, 1981).

The results suggest the presence of at least two $\mathrm{Na}^{+}$transport systems on the luminal membrane of the brain capillary endothelial cell. One is sensitive to furosemide, a diuretic that inhibits $\mathrm{Na}^{+}-\mathrm{Cl}^{-}$or $\mathrm{Na}^{+}-\mathrm{K}^{+}-\mathrm{Cl}^{-}$cotransport in other tissues. The fact that replacement of $\mathrm{Cl}^{-}$with $\mathrm{I}^{-}$leads to decreased ${ }^{22} \mathrm{Na}^{+}$uptake is consistent with $\mathrm{Na}^{+}-\mathrm{Cl}^{-}$cotransport. ${ }^{86} \mathrm{Rb}^{+}$uptake is not inhibited by furosemide, and because this ion can replace $\mathrm{K}^{+}$in $\mathrm{Na}^{+}-\mathrm{K}^{+}$$\mathrm{Cl}^{-}$cotransport (McRoberts et al., 1982), it appears likely that furosemide-sensitive $\mathrm{Na}^{+}$uptake at the BBB occurs by $\mathrm{Na}^{+}-\mathrm{Cl}^{-}$cotransport. Additional evidence that $\mathrm{K}^{+}$is not required in this transport system is that $\mathrm{K}^{+}$does not stimulate ${ }^{22} \mathrm{Na}^{+}$uptake as seen with $\mathrm{Na}^{+}-\mathrm{K}^{+}-\mathrm{Cl}^{-}$cotransport (McRoberts et al., 1982; Warnock and Eveloff, 1982). In fact, in the experiments shown in Table $3, \mathrm{~K}^{+}$actually inhibited ${ }^{22} \mathrm{Na}^{+}$uptake, even when the second $\mathrm{Na}^{+}$ transport system was maximally inhibited with amiloride. This could mean that $\mathrm{K}^{+}$inhibits $\mathrm{Na}^{+}-\mathrm{Cl}^{-}$ cotransport without being transported itself or that $\mathrm{K}^{+}$competes with $\mathrm{Na}^{+}$and is transported but that ${ }^{86} \mathrm{Rb}^{+}$cannot substitute for $\mathrm{K}^{+}$in this transport system.

A second transport system involved in $\mathrm{Na}^{+}$ transport at the $\mathrm{BBB}$ is inhibited by low concentrations of the diuretic amiloride. Uptake of ${ }^{86} \mathrm{Rb}^{+}$is also inhibited by amiloride and both amiloride-sensitive ${ }^{22} \mathrm{Na}^{+}$uptake and ${ }^{86} \mathrm{Rb}^{+}$uptake are inhibited by $\mathrm{K}^{+}$. Amiloride-sensitive ${ }^{22} \mathrm{Na}^{+}$uptake is largely unaffected by $\mathrm{pH}$ changes between 6.2 and 8.4.

The extremely low $K_{\mathrm{i}}$ for amiloride inhibition of brain $\mathrm{Na}^{+}$uptake in vivo is similar to that found for inhibition of $\mathrm{Na}^{+}$movement through the conductive $\mathrm{Na}^{+}$channel found in some epithelia (Benos, 1982). However, there are several differences. At the $\mathrm{BBB}$, inhibition of $\mathrm{Na}^{+}$transport by amiloride is not apparent when the $\mathrm{Na}^{+}$concentration is 140 $\mathrm{m} M$. In contrast, inhibition of transport through the epithelial $\mathrm{Na}^{+}$channel is affected much less by $\mathrm{Na}^{+}$ concentration (Benos et al., 1979; Edmonds, 1981). 
In some epithelia $\mathrm{K}^{+}$and $\mathrm{Rb}^{+}$do not interact with the epithelial $\mathrm{Na}^{+}$pore (O'Neil and Boulpaep, 1979; Edmonds, 1981) whereas in others they do (Benos et al., 1979; Lewis and Wills, 1980). At the BBB ${ }^{86} \mathrm{Rb}^{+}$uptake was inhibited by amiloride and amiloride-sensitive ${ }^{22} \mathrm{Na}^{+}$uptake was inhibited by $\mathrm{K}^{+}$. Amiloride-sensitive $\mathrm{Na}^{+}$uptake is also present in isolated brain capillaries, where it appears mediated via $\mathrm{Na}^{+} / \mathrm{H}^{+}$exchange (Betz, 1983). However, amiloride-sensitive $\mathrm{Na}^{+}$uptake in vivo is inhibited by much lower concentrations of amiloride and is not as sensitive to $\mathrm{pH}$ changes as it is in isolated capillaries. Therefore, the exact nature of amiloridesensitive $\mathrm{Na}^{+}$transport from blood to brain is unclear, and additional experiments will be required to determine whether an analogous transporter exists in other tissues.

Regardless of the precise mechanisms involved, amiloride- and furosemide-sensitive $\mathrm{Na}^{+}$fluxes at the BBB should be difficult to detect in the usual type of in vivo experiment, as they are not apparent when the plasma $\mathrm{Na}^{+}$concentration is in the physiologic range. It is therefore likely that when administered in a clinical setting these agents would have only a minor impact on $\mathrm{Na}^{+}$movement from blood to brain. However, they do provide useful tools for probing the mechanisms involved in ion transport at the BBB.

Previous investigations demonstrated that isolated brain capillaries contain ouabain-inhibitable

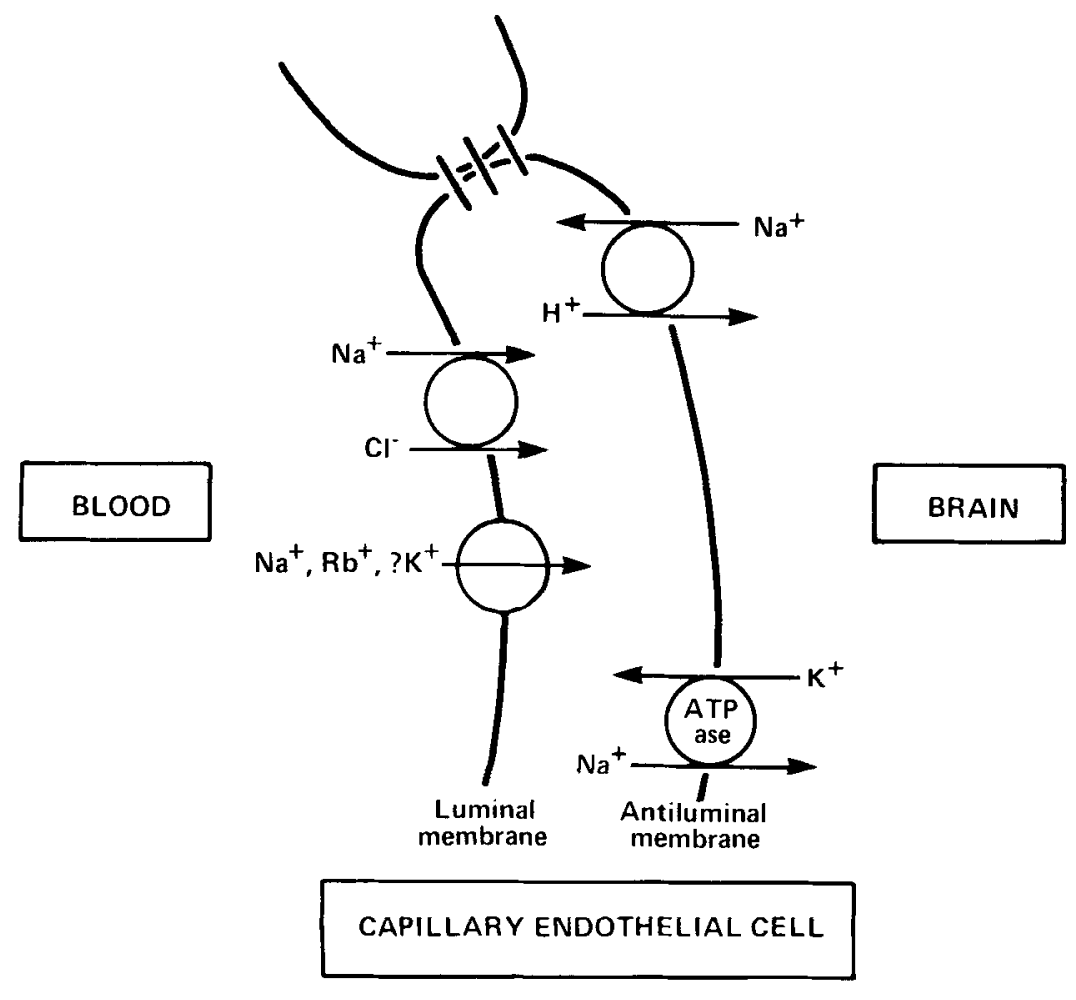

$\mathrm{Na}^{+}, \mathrm{K}^{+}$-ATPase (Goldstein, 1979; Eisenberg and Suddith, 1979) which is found in the antiluminal but not the luminal membrane of brain capillary endothelial cells (Betz et al., 1980). The fact that ouabain did not inhibit uptake of ${ }^{86} \mathrm{Rb}^{+}$in the present study is consistent with the absence of $\mathrm{Na}^{+}, \mathrm{K}^{+}$-ATPase on the luminal membrane. Using similar reasoning, it seems likely that the $\mathrm{Na}^{+} / \mathrm{H}^{+}$exchange transport system found in isolated brain capillaries is also located only on the antiluminal membrane. In isolated brain capillaries, neither ${ }^{22} \mathrm{Na}^{+}$nor ${ }^{86} \mathrm{Rb}^{+}$uptake could be inhibited by furosemide (Betz, 1983) and, therefore, the furosemide-sensitive $\mathrm{Na}^{+}$transport system found in the present study is probably restricted to the luminal membrane.

Figure 6 shows a schematic diagram depicting the apparent distribution of $\mathrm{Na}^{+}$transport systems between the two sides of the brain capillary endothelial cell. This model is based on experiments with isolated brain capillaries where it is principally the antiluminal membrane that is exposed and on experiments reported here using the intracarotid injection where only the luminal membrane is exposed. The polar distribution of ion transport systems is similar to that observed in all ion-transporting epithelial cells where absorption or secretion of water is linked to transcellular ion fluxes. It appears likely that the brain capillary is also capable of transcellular secretion of fluid. According to the model shown in Fig. 6 this might involve entry of
FIG. 6. Schematic diagram for the proposed distribution of $\mathrm{Na}^{+}$transport systems in brain capillary endothelial cells. 
$\mathrm{Na}^{+}$down its concentration gradient across the luminal membrane through either $\mathrm{Na}^{+}-\mathrm{Cl}^{-}$cotransport or the amiloride-sensitive uptake system. Then intracellular $\mathrm{Na}^{+}$would be pumped out of the endothelial cell against a gradient into the brain extracellular space. Simultaneous movement of an anion such as $\mathrm{Cl}^{-}$should also occur to maintain neutrality. Transcellular flux of water would follow the net movement of salt from blood to brain to maintain isotonicity.

In summary, the presence of $\mathrm{Na}^{+}$and $\mathrm{K}^{+}$transport systems in the BBB have been investigated in vivo and compared with studies with isolated brain capillaries in vitro (Betz, 1983). The distribution of $\mathrm{Na}^{+}$transport systems in the brain capillary endothelial cells appears well designed to facilitate transcellular movement of salt and water from blood to brain. Further investigations will be required to determine how this transcellular flux is regulated and the exact role of the BBB in fluid and electrolyte homeostasis in brain.

Acknowledgments: I thank Dr. G. W. Goldstein for helpful discussions and review of the manuscript. This work was supported by grant HL26480 from the National Institutes of Health and was completed while the author was an Established Investigator of the American Heart Association.

\section{REFERENCES}

Benos D. J. (1982) Amiloride: A molecular probe of sodium transport in tissues and cells. Am. J. Physiol. 242, C131C145.

Benos D. J., Mandel L. J., and Balaban R. S. (1979) On the mechanism of the amiloride-sodium entry site interaction in anuran skin epithelia. J. Gen. Physiol. 73, 307-326.

Betz A. L. (1982) Sodium transport at the blood-brain barrier in vivo. The Physiologist 25, 335 .

Betz A. L. (1983) Sodium transport in capillaries isolated from rat brain. $J$. Neurochem. 41, 1150-1157.

Betz A. L., Firth J. A., and Goldstein G. W. (1980) Polarity of the blood-brain barrier: Distribution of enzymes between the luminal and antiluminal membranes of brain capillary endothelial cells. Brain Res. 192, 17-28.

Bouldin T. W. and Krigman M. R. (1975) Differential permeability of cerebral capillary and choroid plexus to lanthanum ion. Brain Res. 99, 444-448.

Bradbury M. (1979) The Concept of a Blood-Brain Barrier, pp. $1-36 ; 214-259$. John Wiley, New York.

Davson H. and Segal M. B. (1970) The effects of some inhibitors and accelerators of sodium transport on the turnover of ${ }^{22} \mathrm{Na}$ in the cerebrospinal fluid and the brain. J. Physiol. (Lond.) 209, 131-153.

Dorovini-Zis K., Anders J. J., and Brightman M. W. (1980) Cerebral endothelium, blood-brain barrier and the astrocyte membrane, in The Blood-Retinal Barriers (Cunha-Vaz J. G., ed.), pp. 65-79. Plenum Press, New York.

Edmonds C. J. (1981) Amiloride sensitivity of the transepithelial electrical potential and of sodium and potassium transport in rat distal colon in vivo. J. Physiol. (Lond.) 313, 547-559.

Eisenberg H. M. and Suddith R. L. (1979) Cerebral vessels have the capacity to transport sodium and potassium. Science 206, $1083-1085$.

Gjedde A. (1981) High- and low-affinity transport of D-glucose from blood to brain. $J$. Neurochem. 36, 1463-1471.

Goldstein G. W. (1979) Relation of potassium transport to oxidative metabolism in isolated brain capillaries. J. Physiol. (Lond.) 286, 185-195.

Lewis S. A. and Wills N. K. (1980) Interaction between apical and basolateral membranes during $\mathrm{Na}^{+}$transport across tight epithelia. J. Gen. Physiol. 76, 3a.

McRoberts J. A., Erlinger S., Rindler M. J., and Saier M. H. (1982) Furosemide-sensitive salt transport in the Madin-Darby canine kidney cell line. J. Biol. Chem. 257, 2260-2266.

Milhorat T. H., Hammock M. K., Fenstermacher J. D., Rall D. P., and Levin V. A. (1971) Cerebrospinal fluid production by the choroid plexus and brain. Science 173, 330-332.

Oldendorf W. H. (1971) Brain uptake of radiolabeled amino acids, amines, and hexoses after arterial injection. J. Physiol. (Lond.) 221, 1629-1639.

Oldendorf W. H. and Braun L. D. (1976) $\left[{ }^{3} \mathrm{H}\right]$ Tryptamine and ${ }^{3} \mathrm{H}-$ water as diffusible internal standards for measuring brain extraction of radiolabeled substances following carotid injection. Brain Res. 113, 219-224.

O'Neil R. G. and Boulpaep E. L. (1979) Effect of amiloride on the apical cell membrane cation channels of a sodium-absorbing, potassium-secreting renal epithelium. J. Membr. Biol. 50, 365-387.

Pardridge W. and Oldendorf W. H. (1975) Kinetics of blood-brain barrier transport of hexoses. Biochim. Biophys. Acta 382, $377-392$.

Pollay M. and Curl F. D. (1967) Secretion of cerebrospinal fluid by the ventricular ependyma of the rabbit. Am. J. Physiol. $213,1031-1038$

Pollay M., Stevens A., Estrada E., and Kaplan R. (1972) Extracorporeal perfusion of choroid plexus. J. Appl. Physiol. 32, 612-617.

Rosenberg G. A., Kyner W. T., and Estrada E. (1980) Bulk flow of brain interstitial fluid under normal and hyperosmolar conditions. Am. J. Physiol. 238, F42-F49.

Smith Q. R., Johanson C. E., and Woodbury D. M. (1981a) Uptake of ${ }^{36} \mathrm{Cl}$ and ${ }^{22} \mathrm{Na}$ by the brain-cerebrospinal fluid system: Comparison of the permeability of the blood-brain and bloodcerebrospinal fluid barriers. $J$. Neurochem. 37, 117-124.

Smith Q. R., Woodbury D. M., and Johanson C. E. (1981b) Uptake of ${ }^{36} \mathrm{Cl}$ and ${ }^{22} \mathrm{Na}$ by the choroid plexus-cerebrospinal fluid system: Evidence for active chloride transport by the choroidal epithelium. $J$. Neurochem. 37, 107-116.

Wallenstein S., Zuckler C. I., and Fleiss J. L. (1980) Some statistical methods useful in circulation research. Circ. Res. 47, $1-9$.

Warnock D. G. and Eveloff J. (1982) $\mathrm{NaCl}$ entry mechanisms in the luminal membrane of the renal tubule. Am. J. Physiol. 242, F561-F574.

Wright E. M. (1972) Mechanisms of ion transport across the choroid plexus. J. Physiol. (Lond.) 226, 545-571. 